Article

\title{
Effect of income diversification on the financial performance of quoted manufacturing firms in Nigeria
}

\author{
Umar Gunu $^{1}$ and Umar Gunu Suleiman ${ }^{2 *}$ \\ 1 Department of Business Administration, University of Ilorin, Nigeria 1; umargunu@gmail.com \\ 2 Department of Business Administration and Management, Federal Polytechnic, Nasarawa, Nigeria 2; \\ gunu4kaiama@gmail.com \\ * Correspondence: gunu4kaiama@gmail.com; Tel.: +2348037631115
}

Received: 30 October 2020; Accepted: 6 December 2020; Published: 8 December 2020

\begin{abstract}
Corporate diversification is a center of research in strategic management and finance. Many firms are experiencing a decline in their traditional activities' dues to environmental challenges, including competition, inadequate infrastructural facilities, and economic instability. The study examines the effect of income diversification on the financial performance of quoted manufacturing firms in Nigeria. Specifically, it determines the impact of product income segment diversification and non-product income segment diversification on quoted manufacturing firms' financial performance in Nigerian. The study adopted an ex-post facto research design using secondary data of 42 firms from the 63 quoted manufacturing firms in Nigeria for 11 years (2007-2017) period. Structural equation modeling (SEM) is utilized for data analysis. The study found that both product income segment diversification and non-product income segment diversification significantly affect the financial performance (ROA and ROCE variables) of quoted manufacturing firms in Nigeria. The study concluded that quoted manufacturing firms' financial performance in Nigeria is significantly affected by product income segment diversification and non-product income diversification. The study recommended that manufacturing firms should strategically diversified to increase their income generation in both the product segment and non-product segment to improve their financial performance.
\end{abstract}

Keywords: Income diversification; Financial performance; Return on Assets (ROA); Return on Equity (ROE); Return on Capital Employed (ROCE); Product-income segment; Non-product-income segment.

JEL codes: M1; M2

\section{Introduction}

Today's business environment is characterized by uncertainty, dynamism, volatility, and hypercompetition, forcing firms, including manufacturing firms, to stumble on new ways of furthering their growth and development drives. Additionally, the current economic situation presents a challenging business atmosphere for corporate firms operating in Nigeria. Though the nation is the largest market hub of Africa, decades in physical infrastructures, especially roads and electricity, corruption, and bureaucratic bottleneck affect firms' growth rate. To worsen the situation, the country's primary revenue drive (crude oil) is experiencing backwardness, making many critical sectors, including the manufacturing sector to be devastated and reducing revenue generation. Many firms are strategically expanding beyond their traditional operational activities to overcome this awful situation. One 
expansion strategy commonly adopted by firms in a situation like this is corporate diversification. Many manufacturing firms in Nigeria are pursuing a diversification strategy by venturing into the production of several related products, exploring other businesses (new subsidiaries), and expanding their operations to new markets with the view of increasing their income. The emerging changes in the world market, including privatization and commercialization; globalization (assisted by improvement in telecommunication and transportation); and trade liberalization, integrations, and agreements, are easing firms' expansion activities.

Corporate diversification literature suggests several theoretical motivations for managers' decision to diversify with a positive and negative effect on performance. Montgomery (as cited in Oweis, 2012) highlights three major theoretical explanations for corporate diversification. Firstly, explanations are based on agency theory in which managers diversify to exploit their gains even at the detriment of the shareholders' right. Accordingly, the supporters of this view argue that managers diversify to raise their strength and reputation, enhance their rewards, safeguard their positions by encouraging investment requiring their particular skills or/and reducing their risk of work (risk of work loss, career, and reputation, etc.). Secondly, the resource-based (economies of scope) argument states that if a firm has excess resources transferable into other industries, it will utilize these resources to take advantage of profit opportunities in different industries and lower its average production cost. Thirdly, an explanation rooted in the market power theory that firms diversify to gain conglomerate power, which emerges from internal capital markets, could be used for cross-subsidization. That is, excess funds created in profitable segments are channeled to subsidize unprofitable ones, and interdependence between conglomerates that choose to compete less aggressively because they face each other in multiple markets.

Accordingly, there are empirical pieces of evidence that provide several reasons for corporate diversification. Rogers (2001) opines that a vital thing to notice regarding the causes of diversification is to combine theories into two categories, notably, claims based on results (performance) and claims based on managers' choice (management judgment). Performance-based arguments fundamentally believe that firms make the most favorable decisions to diversify due to some advantages. Their point of view is based on the benefit of cheaper premiums or increased margins due to synergies in development, distribution, marketing, research, and perhaps other initiatives. Assertions regarding management judgment presume that executives might target non-performance benefits like earnings growth, increasing market shares, escape route from declining demand, and low profit, just as other reasons advanced by agency theory.

Despite the variations, contradictions, and confusions in empirical findings of diversificationperformance relationships, the striking fact is that corporate diversification has substantial implications on the performance of firms in strategic management and finance literature. Corporate diversification might allow firms to save costs and improve revenues owing to dispersal stable costs and economies of scope, reduces firms' risks, and ensures management independence in terms of decreased agency expenses by minimizing cash flow volatility.

Business organizations are planned to make a profit for survival, risk coverage, growth, and expansion. To achieve these, firms must produce quality products that will satisfy customers, withstand competition, and generate income optimally. Corporate firms develop different strategies to increase their performance, including increasing their income from products and other business activities, minimizing running costs, and prudent investment in assets due to liberalization policies. However, global competition, inadequate infrastructural facilities, inconsistent government policies and corruption, and economic instability persistently disrupt business activities, particularly manufacturing firms in Nigeria. Besides, diversification usually comes with structure disorder and reorganization that might result in higher operating costs and corporate governance problems as well as transparency and accountability issues. Subsequently, firms seeking improved performance through diversification might fall into a poor financial performance that endangers their corporate existence. Therefore, it is pertinent to determine how well the diversification of income affects the 
financial performance of the manufacturing firms' financial performance in Nigeria. The study seeks to provide answers to the following research questions:

- How does product-income diversification affect the financial performance of quoted manufacturing firms in Nigeria?

- To what extent does non-product-income diversification impact the financial performance of quoted manufacturing firms in Nigeria?

The study will provide firms in developing nations, particularly, Nigeria access to an empirical study conducted in their peculiar business environment, and the findings therein would guide them in formulating strategies and making relevant investment decisions to optimize competitive advantage. The findings will also help managers evaluate their strength for better diversification in the highly complex market conditions and environmental instability. Furthermore, the findings would be relevant to government agencies, especially the Capital Markets, the Securities and Exchange Commission, and the Ministry of Finance in developing policies, programs, and regulations related to corporate firm performance management to maximize investment returns. Shareholders and investors would guide by the finding in improving their understanding of strategic decisions made by firms relating to investment and expansion.

The study adopted an ex-post facto research design using secondary data from annual reports and archives of forty-two (42) firms selected among the sixty-three (63) quoted manufacturing firms in Nigeria for 11 years (2007-2017 period). Structural equation modeling (SEM), a multivariate statistical analysis technique and extension of the general linear model (GLM) used in analyzing complex structural relationships, models, and regression equations simultaneously, was used for data analysis. The principal finding is that income diversification has a significant effect on quoted manufacturing firms' financial performance in Nigeria. The study's significant contribution is the utilization of path analysis of the structural equation model to investigate the constructs against regression analysis, correlation analysis, chi-square, and T-test. The study has also contributed to the existing body of literature by exposing the income and non-income dimensions of corporate diversification.

The article is structure into five (5) sections, namely, introduction, literature review, data and method, results and discussion, and conclusion. The introduction section summarizes the motivation for the study, the purpose of the study, and its significance. The literature review provides a conceptual and theoretical background for the study as well as gaps from previous studies. The data and method section entails information on the study design, population, sample, data sources, and data analysis methods. The results and discussion section describe the results and interpret them in the context of earlier studies. The last section, the conclusion, summarizes the findings, and outline implications, limitations, and potential directions for further research.

\section{Literature Review}

\subsection{Conceptual Framework}

The firm's diversification and performance are extensively discussed in corporate finance and strategic management literature, and several arguments are advances due to their complex nature (Akkermans, 2010). The majority of diversification definitions center on the notion that diversification finds its root from the word diverse, indicating diversity (Pitts \& Hopkins, 1997). Riswan and Suyono (2016) define corporate diversification as an extension into many various market segments of a successful business. Ramanujam and Varadarajan (1989) see diversification as operating in several different businesses simultaneously by a corporation or an organization's entrance to new operating systems through the strategic expansion process or acquisitions. Moreover, diversification of business is a way of extending its reach, gaining an economy of scale, and producing synergistic impacts on the entire process.

According to Njuguna (2013), diversification can be a concentric, conglomerate, internal, and external. Concentric diversification occurs when a business adds similar goods or markets to create a 
competitive match that enables it to create cohesion and significantly more excellent performance. Conglomerates Diversification happens when a firm broadens its activities against its traditional activities to increase efficiency via corporate marketing or production collaboration. Internal diversification includes selling existing goods in emerging markets by widening the business's geographical capacity, including new consumers (either inside its homeland or in foreign markets), as well as attracting new buyers for product offerings that are new in existing markets. External diversification happens via mergers and acquisitions, where a corporation ventures beyond its existing activities and purchases access to new products or markets. The basic idea in diversification is to increase the firms' income or earnings by developing different products or services and operating in different markets or geographical locations. Accordingly, Wan et al. (2016) opine that diversification of income is the rise of revenue streams or the portion of equilibrium between the various sources, which is commonly acknowledged as a means of self-insurance but not a temporary phenomenon that is merely linked to survival. Wan et al. (2016) argued that enhancing the degree of revenue diversification allows both the amount of earning operations and each variable's volume distribution to differ. Therefore, a company with two revenue sources will be more diversified than one with only one source, and revenue diversification is also used to characterize expansion in the significance of business operations beyond the traditional activities (Daud et al . ,2018).

Income diversification relates to the degree of diversification, which concerns diversification based on a continuous measure or as a business or product count measure (Pitts \& Hopkins, as cited in Datta, Rajagopalan, and Rasheed, 1991 \& Doaei et al., 2015). While Product-income is the revenue generated from the companies' products' sales, Non-product-income diversification is the revenue generated from other companies' business activities. Companies have started leveraging non conventional income-generating channels to the point of institutionalizing it as a strategic business unit. Recently, half of the revenue of banks in the U.S. is derived through non - conventional operations, and this represents not only a diversification of banks into non - conventional operations but also a change in the way banks make income (DeYoung \& Rice, 2004). When manufacturing firms seek to diversify their income streams, they look at activities outside their product line. Specifically, a firm dealing with different products might diversify into providing services that will generate more income. Manufacturing firms are expanding their income generation by engaging in nontraditional activities (non-products segments) from traditional activities (product segments).

On the other hand, performance often relates to efficiency and effectiveness, although firm performance's multidimensional measurement exists. There are numerous scholarships that degree firm performance through a sole indicator (uni-dimensional concept), and researchers are advised to use the dimension(s) most relevant to the study (Santos \& Brito, 2012). Financial performance is often confused with organizational effectiveness, and this has to be clarified. While organizational efficiency includes other facets of the organization's functioning, such as the absence of internal tension and defects, involvement in permissible operations, the procurement of resources, and the achievement of specified objectives; financial success refers to a subset of organizational efficiency that includes operating and economic results (Cameron in Santo \& Brito, 2012). One common and most acceptable way of viewing firm performance is from the viewpoint of stakeholder theory that makes it possible to differentiate among performance referents and results; suggests a framework to identify performance metrics and measurements; and suggests time as well as input feature choices (Santo \& Brito, 2012). The stakeholder theory gives the company's priorities a different viewpoint and, to a degree, clashes with the economic view of maximizing profit. Under this principle, performance measurement requires identifying stakeholders and evaluating the collection of performance results that assess overall satisfaction (Connolly, Conlon, \& Deutsch; Hitt; \& Zammuto in Santo \& Brito, 2012). Investors often used the superiority of firms' financial performance (Cho \& Pucik, 2005; Venkatraman \& Ramanujam, 1986), reflected by profitability, growth, and market value. Profitability reflects the previous capacity of a business to produce gains; growth reflects the firm's previous capacity to expand its size, and market value describes the external appraisal and anticipation of the potential success of businesses. Palich, Cardinal, and Miller (2000) posit that diversification literature typically used these 
two types of performance measures (accounting and market-based measure). Whereas accounting measures provide an evaluative referent (ex-post), market-based measures are more future-oriented measures (ex-ante) of the firms' prospects and are considered as a more long-run perspective (Dubofsky \& Varadarajan, 1987). Accounting measures are appreciated because they reflect realized performance and not affected by shareholders' anticipations (Covas, 2004). The major disadvantages of the accounting-based measure of performance are that it can be manipulated to some extent by management, its inability to reflect future risk or opportunities due to its evaluative character, and it is not well suitable to compare across countries as each country has its accounting standards (Fisher \& McGowan, 1983; Ramanujam \& Varadarajan, 1989; Barney, 1997; \& Covas, 2004). Market measures do not share any of these drawbacks; however, management primarily depends on accounting data when making strategic decisions, limiting the use of solely market-based measures. Furthermore, accounting-based measures reflect realized performance, which might measure the actual and realistic effect of diversification on performance during different situations, including crisis years. Additionally, share prices tend to follow accounting data announcements, which underline the relevance of accounting-based measures (Holzmann, Copeland \& Hayya; \& Fama \& Miller in Akkermans, 2010).

The conceptual model in figure 1 depicts the relationship between income diversification and firms' financial performance. The input factor (income diversification) is conceptualized in two major constructs: product-income and non-product- income segment. The interaction of these diversification constructs with organization factors such as structure, culture, system, and competence, and industry factors such as a change in technology, barrier to entry, growth, concentration, and capital intensity has an impact on the performance of the organization (financial performance) measured in terms of return on assets, return on equity and return on capital employed.

Figure 1. Conceptual Model

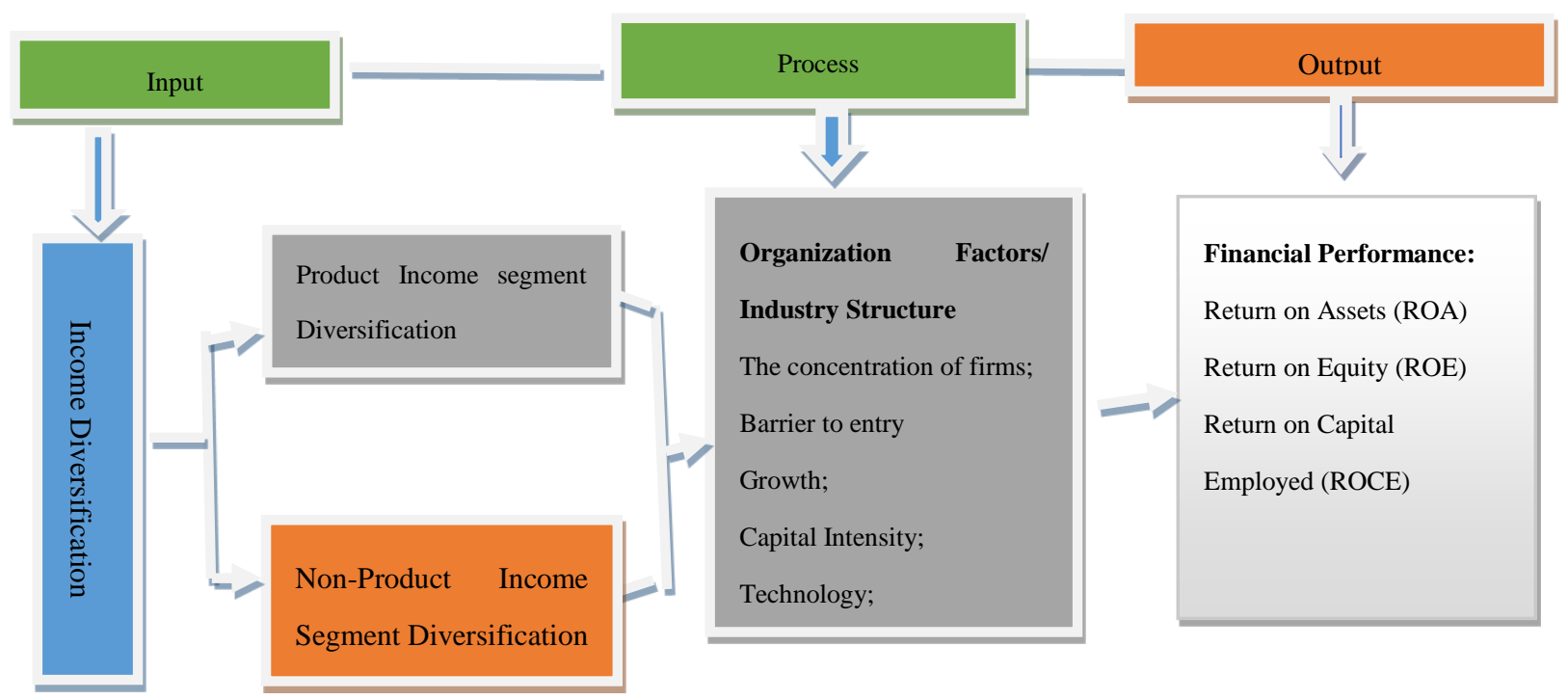

Source: Adapted from Datta, D. K., Rajagopalan, N., \& Rasheed, A. (1991). Diversification and performance: Critical review and future direction. Journal of Management Studies, 28(5), 529-558.

\subsection{Theoretical Framework}

This research is focused on the modern portfolio theory introduced by Markkowitz (1952), as cited in Hsien (2012), which relies on the principle of diversification to investigate were to estimate the overall benefit of a portfolio by choosing an appropriate ratio of assets based on a specified volume of portfolio risk. Modern portfolio theory (MPT) or mean-variance analysis is a statistical method for constructing an asset portfolio, whereas a specified aspect of risk maximizes the anticipated gain. It 
represents and expands investment diversification in which it is less risky to own various kinds of financial assets than to own one kind only. Its central insight is that the risk and return of an asset should not be measured by itself, but by how it relates to the overall risk and return of a portfolio. Thus, by keeping a diversified portfolio of assets, investors can reduce their vulnerability to specific asset risk. When applied by Stiroh and Rumble (2006), modern portfolio theory gives interest income and non-interest income making undertakings as two distinct assets, just as this study treats product income and non-product income diversification as two diverse asset variables.

\subsection{Empirical Framework}

Hsien (2012) examines the influence of income diversification on Islamic banks' success in Malaysia, Saudi Arabia, Kuwait, the United Arab Emirates, Bahrain, and Qatar, wherein they function in a double banking structure besides traditional banks. From 1997 to 2009, accounting data was taken from 68 traditional and 42 Islamic banks. Using various empirical approaches and Panel data regressions, the study finds that both non-financing income segmentation and financing income segmentation have positively influenced financial performance. Although the study was carried out in the non-manufacturing sector (banks) outside Nigeria, its focus on diversification generally and generated income as a measure for diversification specifically significantly influences this study. Also, Waithira (2013) investigates the effects of revenue diversification (interest and non-interest) income on commercial banks' financial performance in Kenya. The study used descriptive design, secondary data (audited financial statements) of the six largest and most profitable commercial banks in Kenya for the period 2008 to 2012 to draw its conclusion. The study also used the regression model and chi-square to test the significance of the study variables. The finding reveals a significant impact and relationship between income diversification variables (financial and non-financial income) and financial performance (return on asset).

Similarly, Stiroh and Rumble (2006) examine whether Prospective diversification benefits justify why U.S. financial investment firms provide an increasing variety of financial services. The study explicitly investigated whether the observed change towards fee-generating, trading revenue, and other non-interest income-generating activities improved the performance of U.S. financial holding companies (FHCs) through regression analysis between 1997 and 2002. The study's main finding is that the cost of increased exposure to risky activities is more than offset by diversification gains, reflecting the dark side of the quest for diversification benefits and having consequences for administrators, managers, investors, and borrowers. Furthermore, Senyo, Olivia, and Musah (2015) conducted a study on income diversification in the Ghanaian banking sector by testing the association amongst banks' non-interest income and profits from 2002 to 2011. The research observed that the largest contributor to the banks' profits remains interest income. Revenue from non-interest sources was also found to have a growing role in periods of short drops in interest revenue. Lastly, Doaei, Anuar, and Ismail (2015) investigated the two dimensions of corporate diversification (product and international diversification) on firms' efficiency jointly. The exciting part of the study is that product diversification is measure in terms of income measured (H.H. index). The findings demonstrate a negative relationship between product diversification and efficiency, international diversification and efficiency, and corporate diversification and efficiency.

\section{Methodology}

\subsection{Design and Population of the Study}

The study adopts an ex-post facto research design because the data required for the study was collected from annual reports and accounts of the companies under investigation. Thus, the study's phenomenon had already taken place, and the data are in existence, making it a quantitative and deductive research approach that sourced data from secondary sources. The data for the period (20072017) are gathered from the annual reports and accounts of the manufacturing firms quoted on the Nigerian stock exchange. This study's population covers all the quoted manufacturing firms by the 
Nigerian stock exchange (NSE). According to the NSE Fact Book (2017), there are sixty-three (63) firms in five (5) sub-sectors of the manufacturing industry (Table I). Manufacturing firms are significantly involved in the production and distribution of goods used by many of the masses, making it one of the Nigerian economies' critical industries. Besides, the firms share similarities in assets and liabilities. Quoted firms are selected because they are legally expected to publish their annual reports, which provide reliable and valid data for any empirical investigation.

Table 1: Manufacturing Firms Classification by Sector and the Sample Size

\begin{tabular}{ccccc}
\hline S/No & Sector & No. of firms & Sampled firms & No. Excluded \\
\hline 1 & Conglomerate & 6 & 5 & 1 \\
\hline 2 & Construction \& Real Estate & 7 & 3 & 3 \\
\hline 3 & Consumer & 26 & 19 & 7 \\
\hline 4 & Industrial & 19 & 12 & 7 \\
\hline 5 & Natural Resources & 5 & 3 & 2 \\
\hline & Total & $\mathbf{6 3}$ & $\mathbf{4 2}$ & $\mathbf{2 0}$ \\
\hline
\end{tabular}

Source: Extracted from the Nigerian Stock Exchange Factbook (2016)

A judgmental sampling technique was used to select 42 firms for the study. The judgmental or purposive sampling technique allows the researcher to select sample elements or representatives of the population to provide reliable and valid information to answer the research questions and meet research objectives. In this study, not all 63 firms (study population) provide reliable and valid data required to make a reasonable conclusion because of truncated data within the study period. Thus, nine firms that are not listed within the study period and 12 firms without required data for the study are automatically excluded from the study, while the remaining 42 constituted the study's sample size.

\subsection{Sources of Data}

The study used secondary data from annual reports and archives of manufacturing firms listed by the Nigeria Stock exchange (NSE) for the study period. The period 2007 to 2017 is a recent period that witnesses significant economic and political developments. The world economic meltdown of 2007/2008, the oil boom period of 2011-2013, Nigeria's recession of 2014-2016 due to the collapse in crude oil prices, and different elections that produced three different democratically elected governments are few examples. Data's reliability and validity are functions of the method by which the data were collected, and the source is otherwise known as the Authority or Reputation of the source (Dochartaigh, 2002). Thus, NSE that authored the fact book from which the study's data was sourced, is an authorized body that provides valid and reliable information on listed firms in Nigeria.

\subsection{Operationalization of Variables}

The study uses two sets of variables: the exogenous and endogenous variables. Endogenous variables which are equivalent to dependent variables in the regression models are proxies as Return on Assets (ROA), Return on Equity (ROE), and Return on Capital Employed (ROCE). The Exogenous variables which are always independent in the SEM equations are product income segment diversification and non-product income segment diversification.

Three main measures are usually used for diversification: Standard Industrial Classification (SIC) codes, Herfindahl or H.H. index, and Entropy Index. While SIC code is a system of identifying business base on activities, the H.H. index is the total square of the sale share of each product of the firm, and the Entropy index includes three significant elements that differentiate it from others indexes; namely, the number of the industry of firm's activities, the number of total sales/assets divide across industry parts, and the power of the part of related and unrelated diversification in a firm (Doaei et al., 2015). H.H. index is commonly used to measure income diversification since it is directly related to the income generated by firms through regular sales. The H.H. measure is defined as $\Sigma \mathrm{iPi} 2 /(\Sigma \mathrm{iPi}) 2$, where $\mathrm{Pi}$ is the proportion of segment sales over the total sales of the firm. However, determining the 
proportion of segment sales here in Nigeria is difficult because of firms' lack of disclosure. Therefore, the firms' revenue is directly used in this study divided into product income segments and nonproduct income. While non-income diversification is determined by the total revenue generated from all business activities less total sales revenue (Total Revenue - Sales Income), income diversification is determined by the total sales revenue less revenue from other business activities (Total Revenue less non-sale income).

This study utilizes accounting-based methods of Return on Assets, Return on Equity, and Return on Capital Employed as the measurements (proxies) of financial performance as follows:

Return on Assets (ROA): Return on Assets (ROA) an accounting-based performance indicator that arrests the efficiency of resource allocation via a firm operation (Waddock \& Graves, 1997). ROA also soundly captures management's ability to utilize assets effectively as it is not affected by the way assets are financed, which is more relevant to diversification study as it may reveal possible diversification inefficiencies (Libby, Libby \& Short, 2010). This is the most commonly used success indicator in prior diversification research (Wang \& Chang, 2006; Ernest \& Jooh, 2010; Adamu, Zubairu, Ibrahim, \& Ibrahim, 2011). The proportion of net income (income accessible to ordinary shareholders) to the book value of total assets is ROA. It is expressed as:

$$
\mathrm{ROA}=\frac{\text { Profit Before Interest and Tax }}{\text { Total Assets }} \times 100 .
$$

Return on Equity (ROE): The proportion of net income (income available to ordinary shareholders) to shareholders' equity is the ROE indicator. From the perspective of stockholders, it is an indicator of a firm's success. Return on equity (ROE) is a metric commonly utilize to measure top management efficiency and to make judgments on executive pay (Pandya and Rao, 1998). Using the benefit for common stockholders, which is the profit after tax and after interest payments, is essential when measuring ROE. (Abdelsalam \& Weetman, 2003). It is expressed as:

$$
\mathrm{ROE}=\frac{\text { Profit After Tax }}{\text { Share capital+Reseraves }} \times 100
$$

Return on Capital Employed (ROCE): ROCE is a measure of firm financial performance used by many diversification studies (Adamu et al., 2011). This ratio is a measure of the efficiency of management in using long-term finances to generate operating profits. ROA measure of firm performance has to be a standard and significant measure among diversification studies (Chakrabarti, Singh, \& Mahmood, 2007). It is defined as the ratio of profit before interest and tax to total assets fewer current liabilities and is calculated as:

$$
\mathrm{ROE}=\frac{\text { Profit Before Interest and Tax }}{\text { Total Assets-Total Liabilitities }} \times 100 .
$$

\subsection{Method of Data Analysis and Models}

The study uses both descriptive and inferential statistics to present and analyze data through Structural Equation Model (SEM) as used by prior studies (Gammelgaard et al., 2012; Vernaik, Midgley \& Devinney, 2005; Fey, Morgulis-Yakushev, Park, \& Bjorkman, 2009). SEM is a multivariate statistical analysis technique and extension of the general linear model (GLM) that is used to analyze complex structural relationships and models, such as confirmatory factor analysis and time-series analyses, and test a set of regression equations simultaneously. The researcher prefers this method because it estimates the multiple and interrelated dependence in a single analysis, and it also allows the use of multiple variables, particularly dependent variables.

Descriptive analysis is used to compute the mean, standard deviation, minimum and maximum values of both the study's endogenous and exogenous variables. Correlation (Bivariate) analysis is used to explain the association between endogenous and exogenous variables. Partial Least Squares (PLS) is used to explore the exogenous variables' effect on the endogenous variables and test the hypotheses. PLS technique is used in two ways: measurement model evaluation and structural model evaluation, giving two collections of linear equations: an internal model that determines relationships between latent variables and an external model that analyzes relationships between latent variables 
and relevant manifest variables. This allows the simultaneous analysis of the path coefficients among latent variables and the path coefficients between these variables and their constructs (measurements) (Fey et al., 2009). This also makes it possible to determine the reliability and validity of the measurement model, as well as determine the structural model. Finally, to avoid inadequacies such as skewed distributions of manifest variables, multi-collinearity within blocks of manifest variables and between latent variables, and data omissions, the PLS approach is resourceful (Cassel, Hackl, \& Westlund, 1999). The Model Specification for PLS equation is given below as capture in the structural model in figure 2:

$$
\begin{aligned}
& \mathrm{ROA}=\beta_{0}+(\mathrm{PID})_{1} \beta_{1}+(\mathrm{NID})_{2} \beta_{2}+(\mathrm{PNID})_{3} \beta_{3+} \varepsilon_{\mathrm{i}} \\
& \mathrm{ROE}=\beta_{0}+(\mathrm{PID})_{1} \beta_{1}+(\mathrm{NID})_{2} \beta_{2}+(\mathrm{PNID})_{3} \beta_{3+} \varepsilon_{\mathrm{i}} \\
& \mathrm{ROCE}=\beta_{0}+(\mathrm{PID})_{1} \beta_{1}+(\mathrm{NID})_{2} \beta_{2}+(\mathrm{PNID})_{3} \beta_{3+} \varepsilon_{\mathrm{i}}
\end{aligned}
$$

Where $\beta=$ beta, $\mathrm{ROA}=$ Return on Assets, $\mathrm{ROE}=$ Return on Equity, ROCE $=$ Return on Capital Employed, $\mathrm{PID}=$ Product income diversification, NID= Non-product income diversification, $\mathrm{PNID}=$ Product and non-product income diversification (this is included in determining the combined effect of the two independent variables on the dependent) and $\varepsilon=$ Error term

Figure 2. Research model

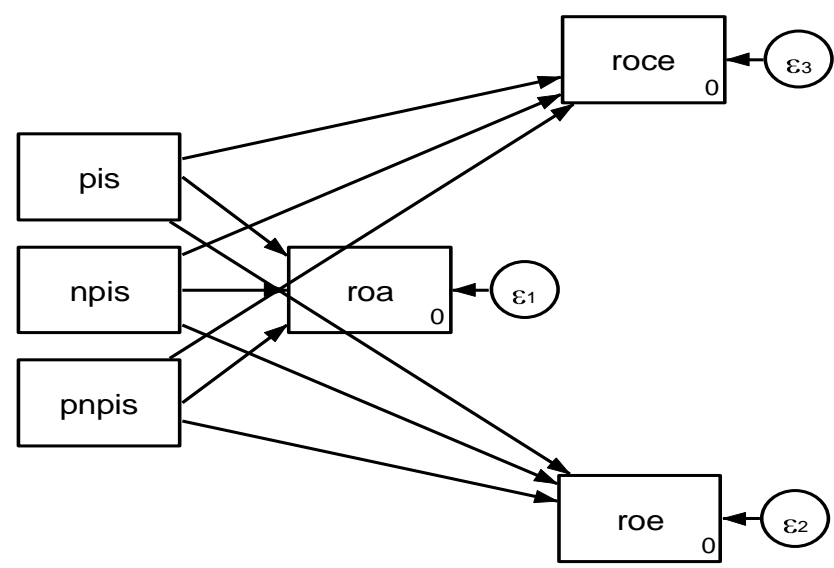

Source: Researcher Construction using STATA 13.0 (2019)

To assess the validity of the measurement model, this study used the criterion suggested by Ali, Liu, and Niazi (2017), and Andreev, Heart, Maoz, and Pliskin (2009). Thus, the study checked with satisfactory results reflective indicators such as item reliability, variable reliability, convergent validity, and discriminant validity. Thus, Andreev et al. (2009) suggested that formative indicators' variable reliability should be performed through a test of Variance Inflation Factor (VIF). A Variance Inflation Factor (VIF) test was conducted with a minimum mean of 1.61 (see table 4.2) to determine the presence of the collinearity problem.

\section{Results and Discussions}

This study analyses the data set through STATA 13.0 and structural equation modeling based on path analysis. Path analysis is widely used to conclude a causal relationship in the data from a longitudinal research design. 
Table 2. Descriptive Statistics

\begin{tabular}{cccccccc}
\hline Variable & Obs & Mean & Std. Dev. & Min & Max & Skewness & Kurtosis \\
ROA & 463 & 0.0386 & 0.1812 & -1.8895 & 0.6756 & 0.0000 & 0.0000 \\
ROE & 463 & 1.6611 & 32.4377 & -20.877 & 697.011 & 0.0000 & 0.0000 \\
ROCE & 463 & 0.0697 & 0.3811 & -3.779 & 1.1312 & 0.0000 & 0.0000 \\
PID & 463 & 7.0258 & 0.8934 & 4.6201 & 9.9531 & 0.6365 & 0.5893 \\
NID & 463 & 5.3338 & 1.1958 & 1.8129 & 8.9779 & 0.9625 & 0.0069 \\
PNID & 463 & 14.2670 & 1.7269 & 9.6418 & 19.9063 & 0.8233 & 0.2271 \\
\hline
\end{tabular}

Source: Researcher's Computation using STATA 13.0

Table 2 explains the detailed summary of descriptive statistics of all variables for quoted manufacturing firms in Nigeria. The results show average performances of $0.38 \mathrm{~K}, \mathrm{~N} 1.66 \mathrm{~K}$, and $0.69 \mathrm{~K}$; minimum of $\mathrm{N}-1.89 \mathrm{~K}, \mathrm{~N}-20.88 \mathrm{~K}, \mathrm{~N}-3.78 \mathrm{~K}$; and maximums of $0.68 \mathrm{~K}, \mathrm{~N} 697$, and N1.13K for ROA, ROE, and ROCE, respectively. This indicates that there is substantial evidence of performance in ROE and ROCE. The implication is that Nigerian quoted manufacturing firms have experienced various levels of financial performance during the period. The standard deviation of 0.18 (ROA) and 0.38 (ROCE) show no significant variation from the average, while the value for ROC (32.44) indicates a significant variation from the average. Similarly, PID, NID, and PNID have averages for diversification of 7.026, 5.334, and 14.267; a minimum of 4.620, 1.813, and 9.642 and maximums of $9.953,8.978$, and 19.91, respectively. This implies various levels of diversifications by the sampled firms within the study period. The standard deviations of 0.89 (ROA), 1.20 (ROE), and 1.73 (ROCE) shows that there is no significant variation from the standard average among sampled quoted manufacturing firms. This implies that diversifications among the firms are evenly spread.

Table 3. Correlation Matrix

\begin{tabular}{llllllllll}
\hline & ROA & ROE & ROCE & PID & NID & PNID & VIF & $R^{2}$ & $\mathrm{Aj} \mathrm{R}^{2}$ \\
ROA & 1.0000 & & & & & & & 0.21 & 0.14 \\
ROE & 0.7144 & 1.0000 & & & & & & 0.10 & 0.03 \\
ROCE & 0.9871 & 0.7164 & 1.0000 & & & & & 0.33 & 0.26 \\
PID & 0.2995 & 0.2231 & 0.2872 & 1.0000 & & & 9.34. & & \\
NID & 0.1356 & 0.1632 & 0.1399 & 0.4135 & 1.0000 & & 2.01 & & \\
PNID & 0.2744 & 0.2499 & 0.2618 & 0.9376 & 0.5704 & 1.0000 & 11.95 & & \\
\hline
\end{tabular}

Source: Computation Researcher's using STATA 13.0

Figure 3. Estimated Analysis

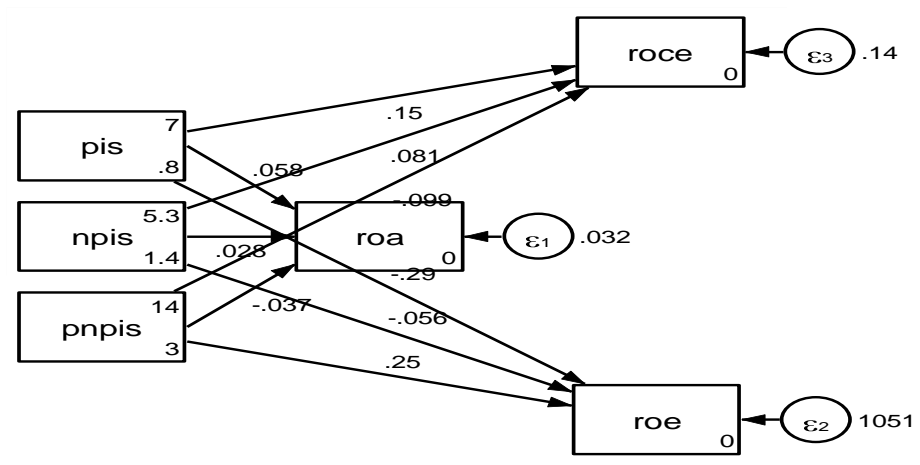

Source: Researcher Computation using STATA 13.0 (2019) 
Table 4. Model Estimates

\begin{tabular}{ccccc}
\hline Beta & Relationship & Coefficient & z-value & p-value \\
$\beta_{1}$ & PID -> ROA & 0.0582 & 2.050 & 0.041 \\
$\beta_{1}$ & PID -> ROE & 0.2904 & -0.006 & 0.955 \\
$\beta_{1}$ & PID -> ROCE & 0.1495 & 2.51 & 0.012 \\
$\beta_{2}$ & NID-> ROA & 0.0284 & 2.88 & 0.004 \\
$\beta_{2}$ & NID -> ROE & 0.0558 & -0.03 & 0.975 \\
$\beta_{2}$ & NID->ROCE & 0.0811 & 3.92 & 0.000 \\
$\beta_{3}$ & PNID->ROA & 0.0365 & -2.25 & 0.025 \\
$\beta_{3}$ & PNID-> ROE & 0.2522 & 0.09 & 0.93 \\
$\beta_{3}$ & PNID>ROCE & 0.0991 & -2.92 & 0.004 \\
\hline
\end{tabular}

Source: Computation Researcher's using STATA 13.0

Table 4 shows a list of coefficients ( $\beta 3)$, $\mathrm{t}$-values, and significance values from the three models above. The left side $(\beta 1, \beta 2, \beta 3)$ specifies the beta and coefficients of the independent variables (PID, NID, and PNID) used for performance variables (ROA, ROE, and ROCE) respectively. The results show that a $1 \%$ increase in product income diversification (PID) leads to a positive increase of $5.8 \%$, $29 \%$, and $15 \%$ in ROA, ROE, and ROCE, respectively. Similarly, a percentage increase in Non-product income diversification (NID) leads to positive increases of 3\%, 5.6\%, and $8 \%$ in ROA, ROE, and ROCE, respectively. A one percent change in total income diversification results in $4 \%, 25 \%$, and $10 \%$ increases in ROA, ROE, and ROCE, respectively. This means that both product income and non-product income diversification cause increases in ROA, ROE, and ROCE measures of quoted manufacturing firms' financial performance in Nigeria.

The table also shows that product income diversification (PID) has significant $p$-values of 0.041 for ROA and 0.012 for ROCE but an insignificant p-value of 0.955 for ROE at a 5\% level of significance. This means that Product income diversification has a significant effect on Return on Assets and Return on Capital Employed financial performance measures but has insignificant effects on return on equity. Thus, since the two measures of financial performance (ROA and ROCE) have significant p-values, the study rejects the null hypothesis that product income segment diversification has no significant effect on quoted manufacturing firms' financial performance in Nigeria. Similarly, the p-values of 0.004 and 0.000 of Non-product income diversification (NID) for ROA and ROCE indicate a significant value at a $5 \%$ level of significance while 0.975 indicates an insignificant p-value. Therefore, the study rejected the assumption that non-product income diversification has no significant effect on quoted manufacturing firms' financial performance in Nigeria. The implication is that both product income diversification and non-product income diversification significantly affect the financial performance of quoted manufacturing firms in Nigeria.

This result is in line with Stiroh and Rumble's (2006) findings that diversification gains are more than offset by the costs of increased exposure to volatile activities. Waithira (2013) also found a significant relationship between income diversification variables (financial and non-financial income) and financial performance (return on asset) of the firms. More so, Hsien (2012) found that both nonfinancing income segmentation and financing income segmentation have positive influences on financial performance. However, the result differs from Doaei et al. (2015) study, which reveals a negative relationship between product diversification, using product income as a measurement (H.H. index) and efficiency, and Shen, et al. (2011) study that reveals that product diversification measure by-product income (H.H. index and entropy) has an inverse U-shaped relationship with firm performance.

\section{Conclusions and Recommendation}

The result reveals a significant effect of Product income diversification (PID), Non-product income diversification (NID), and product and non-product income diversification (PNID) on financial performance variables (ROA and ROCE) of quoted manufacturing firms in Nigeria. Income 
diversification of Quoted manufacturing firms in Nigeria is not a transient phenomenon or one just associated with survival, but a strategy associated with success in achieving competitive advantage as it has a significant effect on firms' financial performance. Thus, under the context of environmental uncertainty, quoted manufacturing firms in Nigeria must avoid an extended period of dependence on only one- or two income sources.

Base on the findings, the study recommended that quoted manufacturing firms in Nigeria should strategically diversified to increase their income generation in both product segments, the non-product segment, with the view of improving their financial performance.

The study is limited first by the generalizability of the findings to other empirical contexts from the study's empirical context (quoted manufacturing firms in Nigeria). This is due to the limited number of the sample used and the inability to use all manufacturing firms. Second, the challenge in measuring diversification using available data to meet international standards. Third, the continuous changing of measurements used for diversification due to strategic reorganization and expansion, resulting in new branches, new products, and new subsidiaries. Finally, the philosophical differences in SEM, which assumed the amount of influence rather than a cause-and-effect relationship, might limit the applicability of this study's findings.

Therefore, it is recommended that further studies should be conducted to include more companies (quoted and non-quoted), industries, and years to ensure that longer-term effects are studied. Future research should also seek the possibility of utilizing international standards measures such as Standard Code identification (SCI) and H.H index and diversification dimensions that are capable of putting strategic reorganization and expansion of the study firms into consideration. Subsequent studies should utilize new models such as the mediating effect or include more variables in the model since SEM permits multiples variables.

Author Contributions: The two authors contributed immensely to the article. While the first author, Umar Gunu, Ph.D., help with the design, theoretical and conceptual underpinning, methodological discourse, and general supervision of the article, the second authors, Umar Suleiman Gunu, contributed to the review of related literature, methodology, data analysis and interpretation, and general execution of the write-up.

Funding: This research received no external funding.

Acknowledgments: We acknowledge Aishat Salawudeeen, Ismail Abdulkhadir Musa, Siadu Yahaya, Abubakar Yunusa, Omolekan, Olushola Joshua, Ph.D., and Woli Jimoh for their contribution by making critical suggestions and editing the work. The contributions of scholars, authors whose articles were consulted can never be forgotten.

Conflicts of Interest: We, the authors, declare that there is no conflict of interest regarding this study. No individual or group of individuals has any claim or responsibility thereof, as regards these articles.

\section{References}

Abdelsalam, O. H., \& Weetman, P. (2003). Introducing international accounting standards to an emerging capital market: Relative familiarity and language effect in Egypt. Journal of International Accounting, Auditing, and Taxation, 12(1), 63-84.

Adamu, N., Zubairu, I. K., Ibrahim, Y. M., \& Ibrahim, A. M. (2011). Evaluating the impact of product diversification on the financial performance of selected Nigerian construction firms. Journal of Construction in Developing Countries, 16(2), 91-114.

Akkermans, A. C. A. (2010). The diversification-performance relationship. Modification during financial crises? Conceptual and empirical understanding. (M.sc Thesis). Tilburg University.

Ali, R., Niazi, G. R., \& Liu, Y. (2017). Corporate governance and performance of peer firms: A cross-lagged analysis of an emerging economy. Journal of Applied Business Research, 33(3), 547.

Ali, S., Hashmi, S. H., \& Mehmood, T. (2016). Corporate diversification and firm performance: An inverted Ushaped hypothesis. International Journal of Organizational Leadership 5(1), 381-398.

Andreev, P., Heart, T., Maoz, H., \& Pliskin, P. N. (2009). Validating formative partial least squares (pls) models: Methodological review and empirical illustration. ICIS 2009 Proceedings, 193. Retrieved from http://aisel.aisnet.org/icis2009/193

Barney, J. B. (1997). Gaining and sustaining competitive advantage. Reading: Addison-Wesley. 
Chakrabarti, A., Singh, K., \& Mahmood, I. (2007). Diversification and performance: Evidence from Asian firms. Strategic Management Journal, 28, 101-120.

Cho, H., \& Pucik, V. (2005). Relationship between innovativeness, quality, growth, profitability, and market value. Strategic Management Journal, 26(6), 555-575.

Covas, F. (2004). Testing the excessive risk-taking hypothesis. Unpublished working paper. The University of California.

Daud, S. A., Awotide, B. A., Omotayo, A. O., Omotosho, A. T., \& Adeniyi, A. B. (2018). Effect of income diversification on household income in rural Oyo State, Nigeria. Acta Universitatis Danubius, 14(1).

De Young, R. \& Roland K. (1999). Product mix and earnings volatility at commercial banks: Evidence from a degree of leverage model. Journal of Financial Intermediation, 10, 54-84.

Doaei, M., Anuar, M. A., \& Ismail, Z. (2015).Corporate diversification and efficiency of manufacturing firms listed in Bursa Malaysia. Iranian Journal of Management Studies, 8(4), 523-544.

Dochartaigh, N. O. (2002). The Internet research handbook: A practical guide for students and researchers in the social sciences. London; Thousand Oaks; New Delhi: Sage.

Dubofsky, P., \& Varadarajan, P.R. (1987). Diversification and measures of performance: Additional empirical evidence. The Academy of Management Journal, 30, 597-608.

Ernest H. H. \& Jooh, L. (2010). Profitability and curvilinearity: A study of product and international diversification. The Journal of International Management Studies, 5(1).

Fey, C. F., Morgulis-Yakushev, S., Park, H. J., \& Bjorkman, I. (2009). Opening the black box of the relationship between HRM practices and firm performance: A comparison of MNE subsidiaries in the USA, Finland, and Russia. Journal of International Business Studies, 40 (4), 690-712.

Fisher, F. M., \& McGowan, J. J. (1983). On the misuse of accounting rates of return to infer monopoly profits. The American Economic Review, 73, 82-97.

Gammelgaard. J., McDonald, F., Stephan, A., Tuselmann, H., \& Dorrenbacher, C., (2012). The impact of increases in subsidiary autonomy and network relationships on performance. International Business Review, 21, 11581172.

George, R., \& Kabir, R. (2008). Corporate diversification and firm performance: How does business group affiliation matter? Working paper. Retrieved from http://demo.uib.es/IBEW/IBEW2008/Papaers2008/CorpDiv_BusGroups_July2008.pdf.

Hsien, C., J. (2012). Income diversification and performance of Islamic Banks (PhD. Thesis). Faculty of Humanities, Manchester Business School.

Libby, R., Libby, P. A., and Short, D. G. (2010). Financial accounting. Chicago: McGraw-Hill/Irwin, Inc. 7the ed.

Naman, J. L. \& Slevin, D. P. (1993). Entrepreneurship and the concept of fit: A model and empirical test. Strategic Management Journal 14, 137 - 153.

Njuguna, K. S. (2013). The effects of diversification on the growth of companies listed in the Nairobi securities exchange (M.Sc Thesis). University of Nairobi, Kenyan.

Oweis, A. (2012). The Impact of Corporate Diversification on the Financial Performance of U.S. Bank Holding Companies Pre and Post the Financial Services Modernization Act of 1999 (Ph.D. Dissertation). Claremont Graduate University. Retrieved from http://scholarship.claremont.edu/cgu_etd/58

Palich, L. E; Cardinal, L. B. \& Miller, C. C. (2000). Curvilinearity in the diversification-performance linkage: An examination of over three decades of research. Strategic Management Journal, 21(2): 155-174.

Pandya, A. M. \& Rao, N. V. (1998). Diversification and firm performance: An empirical evaluation. Journal of Financial and Strategic Decisions. 11(2), 67.

Ramanujam, V. \& Varadarajan, P. (1989). Research on corporate diversification: A synthesis. Strategic Management Journal, 10, 523-551.

Riswan, R., \& Suyono, E. (2016). Corporate diversification: Destroying or increasing firm value? Empirical evidence from Indonesia. Corporate Ownership \& Control. 14(4)

Rogers, M. (2001). The effect of diversification on firm performance. The Performance of Australian Enterprises: Innovation, Productivity, and Profitability. Melbourne Institute of Applied Economic and Social Research. The University of Melbourne, Australia.

Santos, J. B., \& Brito, L. A. L. (2012). Toward a subjective measurement model for firm performance. Brazilian Administration Review, 9. Retrieved from http://dx.doi.org/10.1590/S1807-76922012000500007. 
Senyo, D. B., Olivia, A., \& Musah, A. (2015). Income Diversification and Financial Stability of Banks in Ghana. International Journal of Business and Social Science, 6(6), 177.

Shen, H., Wang, D., \& Su, Z. (2011). Diversification and firm performance in China. African Journal of Business Management, 5(27), pp. 10999-11004.

Signaw, J. A; Simpson, P. M. \& Baker, T. L. (1998). Effects of Supplier Market Orientation on Distributor Market Orientation and the Channel Relationship: The Distributor Perspective, Journal of Marketing, 62, 99 - 111.

Stiroh, K. J. \& Rumble, A. (2006). The dark side of diversification: The case of U.S. financial holding companies, Journal of Banking E Finance, 30, 2131-2161.

Vernaik, S., Midgley, D. F., \& Devinney, T. M. (2005). Dual paths to performance: The impact of global pressures on MNC subsidiary conduct and performance. Journal of International Business Studies, 36, 655-675.

Waddock, S. A; \& Graves, S. B. (1997). The corporate social performance-financial performance link. Strategic Management Journal, 18: 303-319.

Waithira, H. G. (2013). Effects of income source diversification on the financial performance of commercial banks in Kenya (Master Thesis). The University of Nairobi.

Wan, J., Li, R., Wang, W., Liu, Z., \& Chen, B. (2016). Income diversification: A strategy for rural region risk management. Sustainability, 8, 1064.

Wang, C., \& Chang, S. (2006). The effect of product diversification strategies on the relationship between international diversification and firm performance. Journal of World Business, 42, 61-79

(C) 2020 by the authors. This article is an open-access article distributed under the terms and conditions of the Creative Commons Attribution (CC BY) license (http://creativecommons.org/licenses/by/4.0/). 